Reprinted from Ameircan Ethnologist 11(4), November 1984.

\title{
methodological issues in the corporation redux
}

I welcome the opportunity to define more precisely the issues about which Brown and I have been amiably arguing for almost 15 years.

Semantic issue. When Brown sees the term "corporation," he thinks "perpetuity." When I see it I think "entity" on the basis of its Latin root and derived definitions, "to make into a body."

Issue on the constitution of a social system. Brown and I differ in our conception of a social system. He divides it into two classes: entities existing in perpetuity and other entities. I divide a social system into at least three major domains: the jural system, the opportunity system, and the antistructural system of antisocial acts (see Appell 1980a, 1980b, 1981). In delineating social entities I am first concerned to discover in what domain they fall. In the jural realm the diagnostic trait is the capacity to enter into jural relations. Whether social entities in any of the three domains have the attribute of perpetuity is a subsidiary, but nevertheless important issue.

Methodological issues. The terms "etic" and emic" have been used in two different semantic frames: contrasting and complementary (see Appell 1973). Goodenough (1964) made the error of using these as contrastive terms: etic was equated with cross-cultural research, emic, with research that attempts to isolate system-specific distinctions. Cross-cultural research and system-specific research, he argued, had different goals, different and incomparable results. But within the logic of the linguistic model, etic and emic are complementary. A phonetic grid is developed from the distinctions found in a variety of languages. This serves as a method of finding meaningful distinctions in a new language, but only when coupled with an abstract analytical or formal system, the phonemic system.

Brown also uses these terms in a contrastive mode, while my argument is based on the complementary model. I do not claim that sociocultural realms of interest are organized on a linguistic base, which would confuse language with communication (see Appell 1980b, 1981). I am only concerned with understanding the methodology of linguistics and generalizing it into a metamethodology which might be productive for the exploration of other sociocultural domains.

My research goals are to develop better methods for describing the jural system of a society so that indigenous distinctions are isolated and the articulation of the jural domain to other societal domains is delineated. This assumes no priority of the jural domain over other domains. For example, I have raised the question whether ritual entification precedes or follows jural entification, which is an empirical question for each situation (Appell 1976b). It does have the advantage of incorporating process into the model.

As indicated in my $A E$ article, the work of Derham (1958) on the nature of jural entities and Hallowell (1943) on property systems provides the basis for an abstract analytical system for the property dimension of the jural domain. I am in the process of building universal grids for each of the aspects of this system: jural isolates, rights and duties, scarce goods and services, and sanctions. From this theoretical position, the disagreement between Brown and me is over what items should be incorporated into the universal grid and what are the proper discovery procedures for isolating system-specific distinctions. However, 
Brown seems to perceive anthropological inquiry to proceed differently. Sometimes I feel his eye is more on the cross-cultural comparison of cultural entities, while mine is on ethnographic description. And since the concepts in my analytical system are relational, they focus on the critical issue of corporateness and for what social purposes this exists.

Issue of corporation with limited life. Maine (1861) is the source of the attribute "perpetuity," which has found its way into the "traditional" methodology through scholarly carelessness. Maine himself only said it was a leading attribute, and his approach has not been without significant criticism in the field of jurisprudence (see, e.g., Derham 1958). Furthermore, the corporation with a limited life does exist It cannot be dismissed from etic consideration, as Brown argues. Instead, it must be incorporated into the universal (etic) grid.

The position that a corporation springs solely from an association of individuals no longer holds (if it ever did) when today in Western legal systems corporations can be created and owned by a trust, another corporation, or an individual. A corporation can be willfully extinguished, or sold to another legal entity; except in rare situations, social groupings, such as descent groups, cannot. Thus the traditional approach, harking back to the state of jurisprudence in the mid-19th century, has been outpaced by the developments in the law and the concepts of the jurists themselves.

\begin{tabular}{|c|c|c|c|c|}
\hline \multirow{2}{*}{$\begin{array}{l}\text { Distinctions } \\
\text { Made by } \\
\text { GNA }\end{array}$} & \multicolumn{2}{|c|}{ Jural Entities } & \multirow{2}{*}{$\begin{array}{c}\text { Jural } \\
\text { Collectivities }\end{array}$} & \multirow{2}{*}{$\begin{array}{c}\text { Jural } \\
\text { Aggregateb }\end{array}$} \\
\hline & Corporations & $\begin{array}{l}\text { Corporate } \\
\text { Social } \\
\text { Groupings } \\
\end{array}$ & & \\
\hline $\begin{array}{l}\text { Ethnographi } \\
\text { c Examples: } \\
\text { Exists in } \\
\text { Perpetuity }\end{array}$ & $\begin{array}{l}\text { General } \\
\text { Electric }\end{array}$ & $\begin{array}{l}\text { Iban Bilek } \\
\text { Descent Group } \\
\text { with Undivided } \\
\text { Rights Over } \\
\text { Group Property }\end{array}$ & $\begin{array}{l}\text { Descent Group } \\
\text { with Rights } \\
\text { Held by } \\
\text { Members }\end{array}$ & $\begin{array}{l}\text { Descent Group } \\
\text { with Rights } \\
\text { Held by } \\
\text { Members }\end{array}$ \\
\hline $\begin{array}{l}\text { Limited } \\
\text { Life }\end{array}$ & $\begin{array}{l}\text { Corporation } \\
\text { Incorporated } \\
\text { for Limited } \\
\text { Life }\end{array}$ & $\begin{array}{l}\text { Rungus } \\
\text { Domestic } \\
\text { Family c }\end{array}$ & $\begin{array}{l}\text { Limited Life } \\
\text { Property-focused } \\
\text { Social Isolate }\end{array}$ & \begin{tabular}{l}
\multicolumn{1}{l}{ Limited Life } \\
Property- \\
Focused Social \\
Isolate
\end{tabular} \\
\hline
\end{tabular}




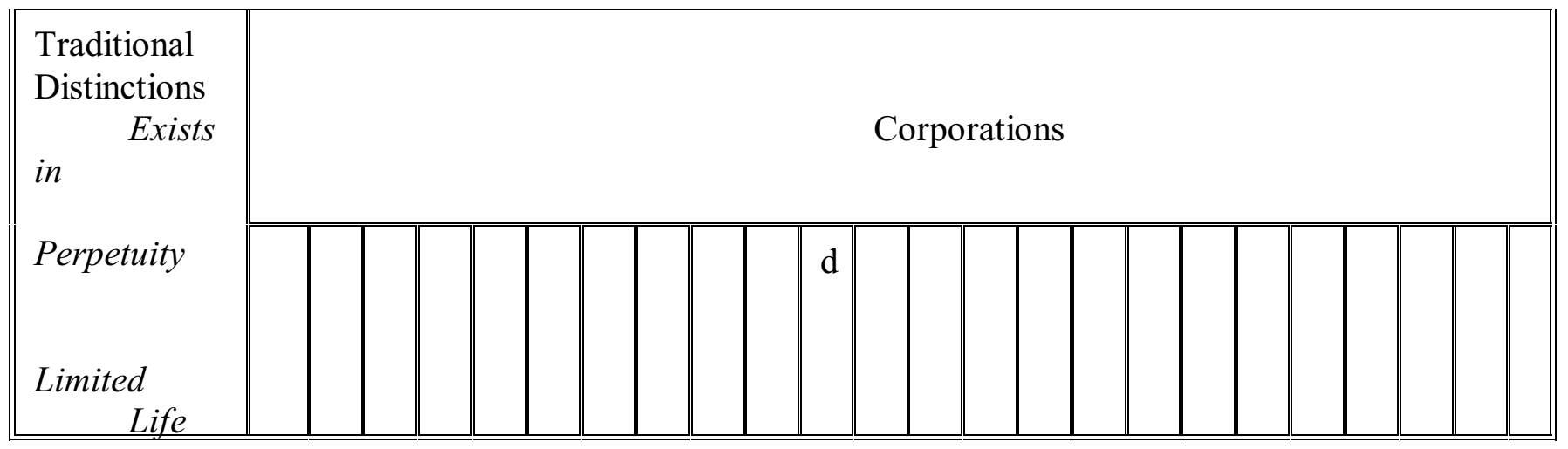

Figure 1. Comparison of theoretical distinctions when applied to the analysis of a jural system.

a jural collectivity: A social grouping in which interests are held in severalty by the individual members but whose social existence is recognized by the jural system in which it is lodged. The jural system thus allows a member of the social grouping to sue on behalf of the other members while still denying the group a separate jural status, a distinct jural personality.

b Jural aggregate: A social grouping in which interests are held in severalty by the individual members and whose social existence is not recognized by the jural system.

c The Rungus domestic family has a limited life but is a jural isolate in the Rungus jural system.

d Under the class of jural entities the two distinctions made by Appell, "corporations" and corporate descent groups," may include entities that exist in perpetuity as well as those that have a limited life. These features of duration of existence are not class-determining but are lower-level attributes that must nevertheless be included in the ethnographic description.

Issue of descriptive adequacy. The traditional methodology when used to describe jural systems overlooks critical distinctions (see Figure 1; I have not included those legal entities in which a social group is not an issue such as individuals, idols, etc., because of limited space). I distinguish corporate groups from corporations. Corporations are detached from any social counterpart, the degree to which in each case needs to be delineated. Their identity is essentially jural, not behavioral. A corporate social grouping, by contrast, is a specific group of individuals that may or may not exist in perpetuity but whose 
members have an undivided interest in the group's assets. This close association between the social entity and its assets is recognized in the jural systems so that the group as a jural entity can enter into jural relations. Descent groups in which the rights over property are held by the individual members severally (e.g., the Land Dayak descent isolate [Geddes 1954; Appell 1971]) are frequently misnamed as corporations or corporate groups under the traditional approach.

The problem of perpetuity, therefore, confuses the analysis of the jural status of descent groups and other social isolates as well. Since descent groups appear to exist in perpetuity, these groups are frequently all classed as corporate whether property rights are held by the members in severalty or corporately. When another social form is found to exist in perpetuity, even though it is not a descent group, it sometimes gets classed as a descent group. Thus, many have called the Iban bilek a descent group (Weston 1972; Hoben 1973; Downs 1970, Brown 1976), even though it explicitly incorpoates affines. 1 This is why I believe that an overemphasis on kinship gets in the way of our inquiry (see Appell 1976a for other examples).

Level of law. When I refer to a jural system, all of its parts are included. In the United States this includes the levels of municipal, state, and federal law. With Moore (1978), I do not see what analytical advantage is gained by referring to the universal processes of order and dispute resolution found in every social grouping as law. The order found in a sandlot baseball game and the methods used to resolve disputes may have certain analogies to law, but to term them as law confuses the issues. This does not mean that there is no social order among members of the descent isolate, or no method for resolving disputes between members, or that it is not a social entity in other domains than the jural. Even if we accept Brown's argument that the descent isolate has its own law, the descriptive problem does not disappear. We still have to ask whether it has the capacity to enter into jural relations at that particular level.

But we argue past ourselves. Brown and I have different research goals and different methodologies. My method provides a description of a social system more faithful to the indigenous distinctions. It cleaves the tissues of a society more according to its own natural divisions than does the criterion of perpetuity. As a result it is more powerful and productive, the proof of which is in its empirical testing: ethnography.

\section{notes}

1 Brown (1984:personal communication) has drawn my attention to the fact that while he classified the Iban bilek as a descent group--he would prefer now to call it a kinship group--he made the point that it is not based on descent alone but on "voluntary association and localization as well" (Brown 1976:121). 


\section{references cited}

Appell, G. N.

1971 Systems of Land Tenure in Borneo: A Problem in Ecological Determinism. Borneo Research Bulletin 3:17-20.

1973 The Distinction Between Ethnography and Ethnology and Other Issues in Cognitive

Structuralism. Bijdragen tot de Taal-, Landen Volkenkunde 129:1-56.

1976a Introduction The Direction of Research in Borneo: Its Past Contributions to Anthropological

Theory and Its Relevance for the Future. In The Societies of Borneo: Explorations in the Theory of

Cognatic Social Structure. AAA Special Publication No 6. G. N. Appell, ed. pp 1-15.

Washington, DC: American Anthropological Association.

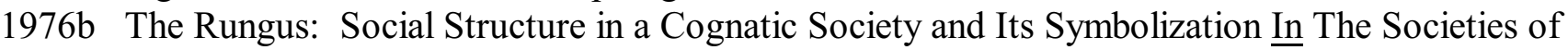

Borneo: Explorations in the Theory of Cognatic Social Structure. AAA Special Publication No 6.

G. N. Appell, ed. pp 66-86. Washington, DC: American Anthropological Association.

1980a Talking Ethics: The Uses of Moral Rhetoric and the Function of Ethical Principles. In Ethical

Problems of Fieldwork. Joan Cassell and Murray L Wax, ed. Social Problems 27(3):350-357.

1980b Epistemological Issues in Anthropological Inquiry: Social Structuralism, Cognitive

Structuralism, Synthetic Structuralism and Opportunism, Part 1. Canberra Anthropology 3(2):1-27.

1981 Epistemological Issues in Anthropological Inquiry: Social Structuralism, Cognitive

Structuralism, Synthetic Structuralism and Opportunism, Part 2. Canberra Anthropology 4(1):1-22.

Brown, D. E.

1976 Principles of Social Structure. London: Duckworth.

Derham, D. P.

1958 Theories of Legal Personality In Legal Personality and Political Pluralism. Leicester C. Webb, ed. pp. 1-19. Carlton: Melbourne University Press.

Downs, R. E.

1970 Problems of Explanation in Anthropology. In Anniversary Contributions to Anthropology: Twelve Essays Published on the Occasion of the 40th Anniversary of the Leiden Ethnological Society W D.O., pp. 4-63. Leiden: E. J. Brill.

Geddes, William R. 
1954 The Land Dayaks of Sarawak. Colonial Research Studies 14. London: Her Majesty's Stationery Office.

Goodenough, Ward H.

1964 Introduction In Explorations in Cultural Anthropology. Ward H. Goodenough, ed. pp. 1-24. New York: McGraw-Hill.

Hallowell, A. Irving

1943 The Nature and Function of Property as a Social Institution. Journal of Legal and Political Sociology 1:115-138.

Hoben, Alan

1973 Land Tenure among the Amhara of Ethiopia. Chicago: University of Chicago Press.

Maine, Henry Sumner

1861 Ancient Law. Boston: Beacon Press.

Moore, Sally Falk

1978 Law as Process: An Anthropological Approach. London: Routledge \& Kegan Paul. Weston, S.

1972 Samoan Social Organization: Structural Implications of an Ambilineal Descent System. Ph.D. dissertation. Department of Anthropology, University of California, Los Angeles.

G. N. Appell

Brandeis University

Submitted 20 January 1984

Accepted 24 January 1984

Final revisions received 21 March 1984 
